\title{
Artritis Encefalitis Virus u koza u Republici Hrvatskoj u razdoblju od 2012. do 2019. godine - serološko i molekularno istraživanje
}

\author{
B. Roić, D. Brnić, A. Kostelić, A. Jungić, Z. Romac, L. Jemeršić, T. Keros, \\ J. Prpić i D. Vincek
}

\section{Sažetak}

Artritis-encefalitis koza (AEK) je neizlječiva virusna bolest proširena $u$ većini zemalja koje se bave intenzivnim uzgojem koza. Ekonomsko značenje ove bolesti očituje se uginućem jaradi, smanjenim prirastom i mliječnošću, prijevremenim lučenjem iz uzgoja. U razdoblju od 2012. do 2019. godine na području 16 županija u Republici Hrvatskoj pretraženo je 10715 uzoraka krvi, a tijekom tog osmogodišnjeg razdoblja specifična protutijela za virus AEK bila su potvrđena u 4353 uzoraka krvnog seruma pa zaključno možemo govoriti o seroprevalenciji od 40,62 $\%$. Rezultati genotipiziranja odabranih sojeva LVMP ukazuju na cirkulaciju genetske skupine A i B u populaciji koza i to su prva takva istraživanja provedena u Hrvatskoj.
Dokaz prisutnosti genotipa A u stadu koza $\mathrm{u}$ kojem je istovremeno dokazan i genotip B ukazuje na činjenicu da sojevi LVMP nisu ograničeni na jednu vrstu već da sojevi MVV koji se uglavnom nalaze u ovaca, cirkuliraju i u koza. Rezultati višegodišnjeg istraživanja provedenog na Hrvaskom veterinarskom institutu ukazuju na široku rasprostranjenost virusa AEK u uzgojima koza u Republici Hrvatskoj. Ako znamo da jednom zaražena jedinka ostaje doživotni nositelj i prenositelj virusa postavlja se pitanje uspješnosti cijele proizvodnje pa je stoga jedini dugoročno održiv način uzgoja uzgoj slobodan od AEK.

Ključne riječi: artritis encefalitis virus, koze, seroprevalencija, metoda lančane reakcije polimerazom (PCR), filogeneza

Dr. sc. Besi ROIĆ* , dr. med. vet., znanstvena savjetnica (dopisni autor, e-mail: roic@veinst.hr), dr. sc. Dragan BRNIĆ, dr. med. vet., znanstveni suradnik, dr. sc. Andreja JUNGIĆ, dr. med. vet., stručna savjetnica, Hrvatski veterinarski institut, Zagreb, Hrvatska; dr. sc. Zdravka ROMAC, dr. med. vet., poslijedoktorandica, Hrvatski veterinarski institut, Veterinarski zavod Split, Hrvatska; dr. sc. Lorena JEMERŠIĆ, dr. med. vet., izvanredna profesorica, dr. sc. Tomislav KEROS, dr. med. vet., znanstveni savjetnik, dr. sc. Jelena PRPIĆ, mol. biolog, znanstvena suradnica, Hrvatski veterinarski institut, Zagreb, Hrvatska; dr. sc. Antun KOSTELIĆ, dr. med. vet., izvanredni profesor, Agronomski fakultet Zagreb, Hrvatska; dr. sc. Dragutin VINCEK, Varaždinska županija, Upravni odjel za poljoprivredu, Hrvatska 


\section{Uvod}

Artritis-encefalitis koza (AEK) je virusna bolest proširena $u$ svjetskim razmjerima. Klinički se očituje kao: progresivni leukoencefalomijelitis (tetraplegija) u jaradi do 6 mjeseci starosti i redovito završava uginućem; kronični artritis (karpalni zglobovi) i mastitis u odraslih koza te sporadična, sporo progredirajuća intersticijska upala pluća (Narayan i Cork, 1985., Dawson, 1988.). Štete koje bolest uzrokuje su višestruke, a očituju se uginućem jaradi, smanjenom mliječnošću, prijevremenim izlučenjem iz uzgoja i troškovima liječenja i preventive (Brinkhof i sur., 2010.). Do sada su svi pokušaji liječenja bolesnih životinja i izrada vakcine ostali bezuspješni (Torsteinsdottir i sur., 2007.). Budući da imuni odziv $u$ inficiranih životinja ne inaktivira uzročnika, one ostaju doživotni nositelji i prenositelji virusa (Kuzmak i sur., 2003.).

Uzročnik pripada porodici Retroviridae, potporodici Orthoretrovirinae, rod Lentivirus. Filogenetskom analizom ustvrđeno je da su virus Maedi-Visna u ovaca (MVV) i virus artritis encefalitis koza (AEK) antigeno blisko srodni, ali genski potpuno različiti, da dijele mnoge zajedničke osobine te da su oba virusa svrstana u lentiviruse malih preživača (LVMP) (engl. Small ruminant lentiviruses, SRLV) (Olech i sur., 2012.).

Do danas je poznato pet osnovnih genskih skupina LVMP označenih od A E. Genotipovi A i B, opisani su kod MVV i AEK, prošireni su po cijelom svijetu, dok su genotipovi C, D i E geografski ograničeni. Genotip A je visoko heterogen i sadrži najmanje 13 podtipova od A1 do A13 (Kuhar i sur., 2013.), dok je genotip B manje kompleksan i sadrži 3 podtipa B1 do B3 (Bertolotti i sur., 2011.). Virusni soj izdvojen iz koza u Norveškoj označen je kao genotip C, a genotip D odgovara izolatima izdvojenim u Švicarskoj i Španjolskoj. Genotip E je dokazan u
Italiji i sadrži dva podtipa E1 i E2 (Reina i sur., 2010.). Filogenetska analiza LVMP virusa ukazuje na prijenos infekcije među vrstama malih preživača i mora se uzeti u obzir u kontroli bolesti (Leroux i sur., 1997.).

Programi suzbijanja bolesti obuhvaćaju sustavnu serološku provjeru stada primjenom metoda propisanih od strane Međunarodnog ureda za praćenje epizootija (OIE, 2008.) i rano uklanjanje svih pozitivnih reaktora kao trajnog izvora infekcije. Uvid u putove širenja virusa daje molekularna epidemiologija koja je temeljena na genskoj karakterizaciji. Primjena molekularnih metoda dijagnostike omogućava ne samo dokaz uzročnika i količinu MVV i AEK provirusa u uzorku, već i genetsku karakterizaciju sojeva specifičnih za zemlju i/ili regiju u kojoj je bolest prisutna (Olech i sur., 2018.).

Artritis i encefalitis koza je $u$ Hrvatskoj prvi puta službeno dokazan 1996. godine (Čač i sur., 1996., 2000.). Promet zaraženih rasplodnih koza u RH ni do danas nije zakonski reguliran što pogoduje nesmetanom širenju bolesti te ju susrećemo na većini farmi u Hrvatskoj. Pritom udio zaraženih koza unutar stada može biti i do $100 \%$, a prosječna prevalencija je $70 \%$ te bolest prouzroči velike gubitke $\mathrm{u}$ intenzivnom uzgoju mliječnih koza u Hrvatskoj (Kostelić i sur., 2012., 2013.).

Cilj ovog rada bio je istražiti rasprostranjenost AEK $u$ uzgojima koza u razdoblju od 2012. do 2019. godine primjenom seroloških metoda pretraživanja te metodama lančane reakcije polimerazom (PCR), sekvenciranja i filogenetike ustvrditi genotipove sojeva virusa AEK. Ovo je ujedno i prvo sustavno višegodišnje serološko istraživanje AEK provedeno u Republici Hrvatskoj te prvi podatci o zastupljenosti genotipova. 


\section{Materijal i metode}

\section{Uzorkovanje krvi koza}

Uzorci za pretragu prikupljali su se u okviru projekata Vijeća za istraživanje u poljoprivredi Ministarstva poljoprivrede $\mathrm{u}$ pod nazivom „Utjecaj artritisa encefalitisa koza na konkurentnost proizvodnje kozjeg mlijeka" (2012.2014.) i „Upravljanje zdravljem stada s ciljem povećanja konkurentnosti i očuvanja okoliša u proizvodnji ovčjeg i kozjeg mesa i mlijeka" (2015.-2017.) u suradnji s Agronomskim fakultetom Sveučilišta u Zagrebu, u okviru godišnje Naredbe o mjerama zaštite životinja od zaraznih i nametničkih bolesti i njihovom financiranju u 2015. godini te $u$ sklopu pretraživanja na zahtjev vlasnika pojedinih uzgoja koza.

Krv se za serološku pretragu uzimala od svake životinje punkcijom venae jugularis, 5-10 $\mathrm{ml} \mathrm{u}$ epruvetama bez antikoagulansa i dostavljala $u$ Laboratorij za serološku dijagnostiku virusnih bolesti Hrvatskog veterinarskog instituta $\mathrm{u}$ Zagrebu. Po dolasku $u$ laboratorij provedeno je odvajanje seruma od korpuskularnih dijelova krvi centrifugiranjem u laboratorijskoj

Tabela 1. Ukupan broj pretraženih uzoraka krvi koza na prisutnost protutijela za virus artritis i encefalitisa koza (AEK) u razdoblju od 2012. 2019. godine

\begin{tabular}{|c|c|}
\hline Godina & $\begin{array}{c}\text { Broj serološki } \\
\text { pretraženih uzoraka }\end{array}$ \\
\hline 2012. & 10 \\
\hline 2013. & 2618 \\
\hline 2014. & 1628 \\
\hline 2015. & 1934 \\
\hline 2016. & 1046 \\
\hline 2017. & 2086 \\
\hline 2018. & 1088 \\
\hline 2019. & 305 \\
\hline Ukupno & 10715 \\
\hline
\end{tabular}

centrifugi (Hettich, Njemačka) 10 minuta pri 2000 rpm. Ukoliko serološka pretraga nije uslijedila odmah nakon pripreme, uzorci su pohranjeni na $-20{ }^{\circ} \mathrm{C}$ do izvođenja pretrage.

U razdoblju od 2012. do 2019. godine dostavljena su ukupno 10715 uzoraka krvi koza (Tabela 1.) iz 16 županija u Republici Hrvatskoj. Najveći broj uzoraka dostavljen je iz Međimurske županije 3 938, potom iz Varaždinske 3 755, Istarske 1 011, Zagrebačke 547, Zadarske 378, Koprivničko-križevačke 343, Ličkosenjske 337, a u ostalim županijama pretražen je manji broj uzoraka.

Za potrebe dokazivanja provirusne DNK i ustvrđivanja genotipova virusa AEK tijekom 2015. godine uzorkovani su uzorci pune krvi $(n=29)$ koza pasmine Francuska alpska koza podrijetlom iz dva stada u Međimurskoj ( $n=20)$ i jednog stada u Varaždinskoj županiji u kojih su imunoenzimnim testom (ELISA) ustvrđena protutijela za AEK. Uzorci pune krvi uzeti su punkcijom venae jugularis $\mathrm{u}$ epruvetama s antikoagulansom (EDTA).

\section{Serološke metode}

Svi uzorci seruma pretraženi su komercijalnim imunoenzimnim kompletima (ELISA) na prisustvo protutijela sukladno uputi proizvođača i to prvo probirnim testom (CAEV/MVV Antibody test kit CHEKIT Screening, IDEXX), a nakon dobivenih pozitivnih reakcija potvrdnim testom (CAEV/MVV Antibody test kit CHEKIT Verification, IDEXX).

\section{Molekularne metode}

Izdvajanje provirusne DNK LVMP provedeno je iz $300 \mu \mathrm{L}$ pune krvi koristeći automatizirani sustav za izdvajanje nukleinskih kiselina "iPrep Purification Instrument Platform" (Invitrogen, Carlsbad, CA, USA) te pripadajući komplet za izolaciju DNK iz krvi (iPrep PureLink gDNA Blood) prema uputama proizvođača. 
Dokazivanje provirusne DNK $\mathrm{u}$ predmetnim uzorcima krvi provedeno je množavanjem ciljnih odsječaka gena LVMP korištenjem dva protokola za lančanu reakciju polimerazom u stvarnom vremenu (Real-time PCR), jedan za određivanje genotipa $A$ te drugi za genotip B LVMP (Kuhar i sur., 2013a., 2013b.). Za tu svrhu koristili smo RotorGene Probe PCR kit (Qiagen, Njemačka) sukladno uputama proizvođača (završna koncentracija početnica $400 \mathrm{nM}$ i Taqman probe 200 $\mathrm{nM}$ ) i uređaj RotorGene Q (Qiagen, Njemačka). Za utvrđivanje genotipova sojeva virusa AEK upotrebljen je odsječak pol (DNA polymerase) gena umnožen metodom ugniježđenog (",nested “) PCR-a s početnicama i prema protokolu opisanom u radu Shah i sur. (2004.) Taj protokol je ujedno poslužio i kao dodatna provjera učinkovitosti prethodno navedenih postupaka dokazivanja genoma LVMP metodama PCR u stvarnom vremenu. Za taj postupak korišten je HotStarTaq Plus PCR kit (Qiagen, Njemačka) prema uputama proizvođača (završna koncentracija početnica $300 \mathrm{nM}$ ) i uređaj GeneAmp 9700 PCR System (Applied
Biosystems, Njemačka). Odabrani odsječci pol gena $(n=9)$ veličine 1175 bp su nakon elektroforeze u $2 \%$-tnom agaroznom gelu podvrgnuti ekstrakciji i pročišćavanju. Izravno sekvenciranje $\mathrm{u}$ oba smjera provedeno je u tvrtki Macrogen (Amsterdam, Nizozemska), a za računalnu analizu dobivenih nukleotidnih slijedova korišten je programski paket MEGA 5.

\section{Rezultati}

Tijekom provedenog istraživanja $u$ razdoblju od 2012. do 2019. godine na području 16 županija u Republici Hrvatskoj ukupno je imunoenzimskim testom pretraženo 10715 uzoraka krvnog seruma koza. Testom probira protutijela za virus AEK ustvrđena su u 5160 uzoraka seruma $(48,16 \%)$. Uzorci seruma koza koji su imunoenzimskim testom probira dale pozitivnu reakciju podvrgnuti su ponovnom testiranju potvrdnim testom. Potvrdnim testom ukupno je pretraženo 5160 uzoraka seruma, a pozitivne reakcije su ponovno ustvrđene u 4353 uzorka. Stoga zaključno možemo govoriti o seroprevalenciji od 40,62 \% (Tabela 2.).

Tabela 2. Rezultati pretrage krvi koza za virus artritis i encefalitis koza (AEK) dobiveni imunoenzimskim testom probira i potvrde u razdoblju od 2012. - 2019. godine

\begin{tabular}{|c|c|c|c|c|c|}
\hline \multirow{2}{*}{ Godina } & \multirow{2}{*}{$\begin{array}{c}\text { Broj serološki } \\
\text { pretraženih uzoraka }\end{array}$} & \multicolumn{2}{|c|}{$\begin{array}{c}\text { Pozitivno - probirni } \\
\text { test }\end{array}$} & \multicolumn{2}{|c|}{$\begin{array}{c}\text { Pozitivno - potvrdni } \\
\text { test }\end{array}$} \\
\cline { 3 - 6 } & & Broj & $\%$ & Broj & $\%$ \\
\hline 2012. & 10 & 2 & 20,00 & 1 & 10,00 \\
\hline 2013. & 2618 & 1666 & 63,61 & 1540 & 58,82 \\
\hline 2014. & 1628 & 846 & 51,97 & 672 & 41,27 \\
\hline 2015. & 1934 & 1048 & 54,19 & 881 & 45,55 \\
\hline 2016. & 1046 & 285 & 27,25 & 220 & 21,03 \\
\hline 2017. & 2086 & 709 & 32,78 & 575 & 27,56 \\
\hline 2018. & 1088 & 499 & 35,07 & 388 & 35,66 \\
\hline 2019. & 305 & 105 & 24,92 & 76 & 24,91 \\
\hline Ukupno & 10715 & 5160 & 48,16 & 4353 & 40,62 \\
\hline
\end{tabular}




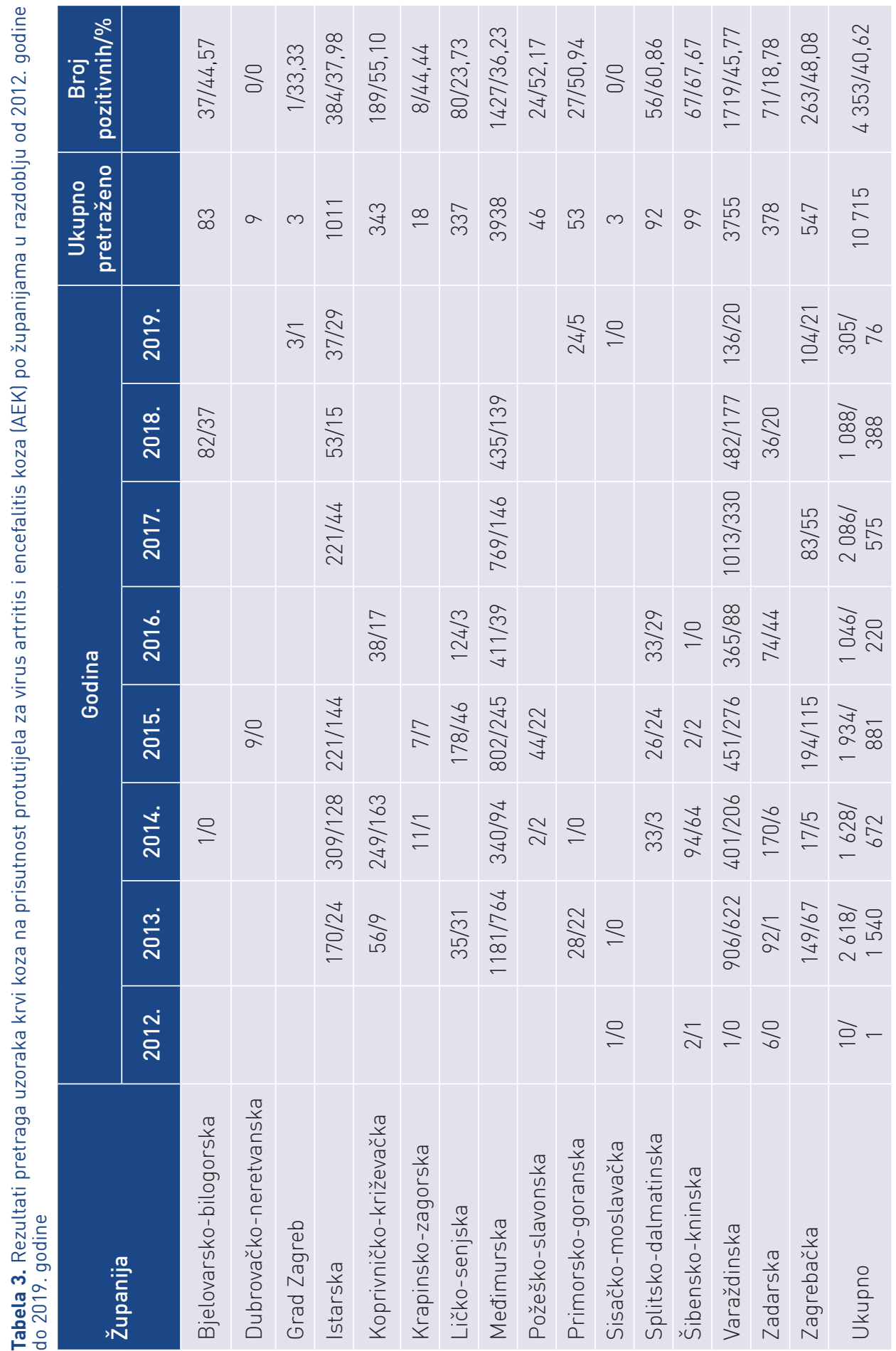




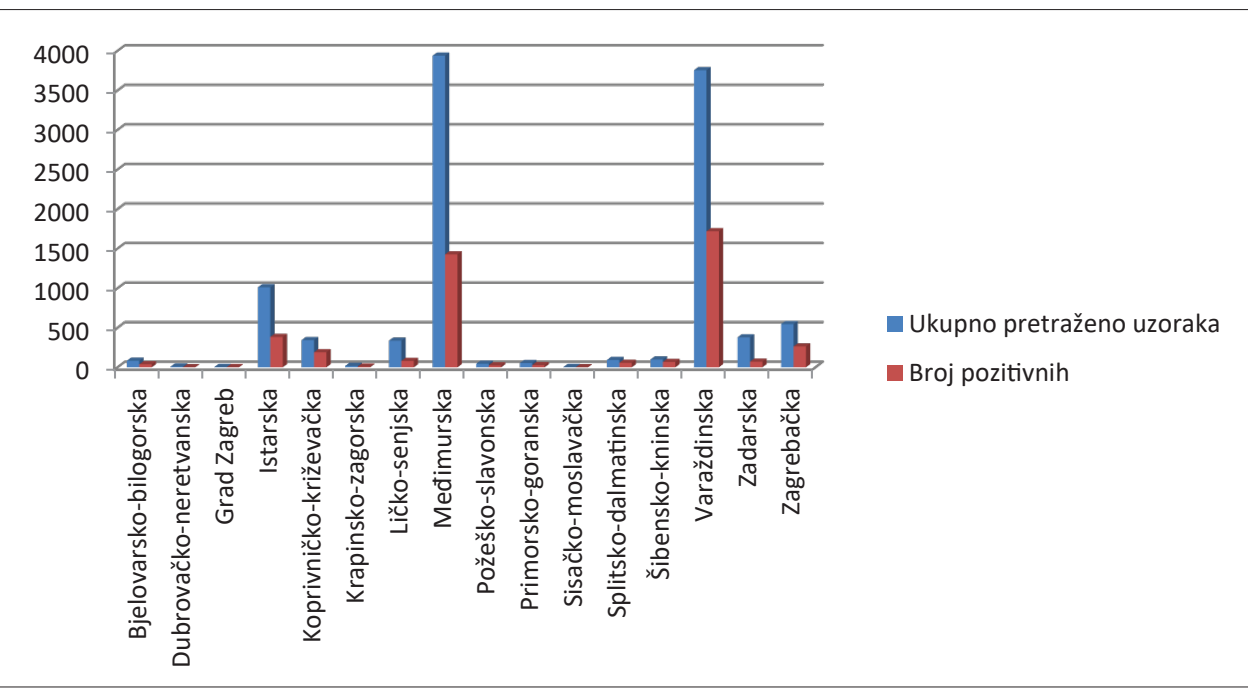

Grafikon 1. Rezultati pretraga uzoraka krvi koza na prisutnost protutijela za virus artritis i encefalitisa koza (AEK) po županijama u razdoblju od 2012. godine do 2019. godine

AEK je serološkim testovima dokazan u svim godinama istraživanja. U Tabeli 2. vidljivo je da je najveći postotak pozitivnih reakcija utvrđen u 2013. godini te su potvrdnim testom protutijela za virus AEK dokazana u 58,82 \% uzoraka. Potom slijede 2015. godina s serprevalencijom od 45,55\% i 2014. godina s seroprevalencijom od $41,27 \%$. U 2012. godini ustvrđena je seroprevalencija od 10,00 \%, ali u toj godini pretražen je i najmanji broj uzoraka.

Seropozitivne životinje dokazane su u 14 od 16 pretraženih županija. Negativne reakcije ustvrđene su u Sisačkomoslavačkoj županiji (3/0) i Dubrovačkoneretvanskoj (9/0) gdje je ujedno pretražen i najmanji broj uzoraka. Najveći postotak pozivnih reakcija ustvrđen je u Sibensko-kninskoj $(67,67 \%)$ i Splitskodalmatinskoj (60,86 \%) županiji, ali je i u tim županijama pretražen i manji broj životinja. Potom slijede Koprivničkokriževačka s 55,10 \%, Požeško-slavonska s 52,17 \%, Primorsko-goranska s 50,94 $\%$ te Krapinsko-zagorska s 44,44 \% i manjim brojem pretraženih uzoraka. Najveći broj pretraženih uzoraka bio je u Međimurskoj županiji 3 938, od kojih je pozitivne reakcije pokazalo 1427 uzoraka seruma (36,23 \%) i Varaždinskoj 3 755, a pozitivne reakcije pokazalo je 1 719 uzoraka seruma odnosno 45,77 \%. U Istarskoj županiji pretraženo je 1011 uzoraka, a pozitivne reakcije pokazalo je njih 384 (37,98 \%), u Zagrebačkoj 547 od kojih je 263 reagiralo pozitivno (48,08 \%), u Zadarskoj 378, a pozitivne reakcije je pokazalo njih 71 (18,78\%). U Koprivničko-križevačkoj županiji je pretraženo 343 uzorka, a pozitivne reakcije su ustvrđene u 189 uzoraka $(55,10 \%)$ i u Ličko-senjskoj županiji od 337 uzoraka 80 ih je bilo pozitivnih $(23,73$ \%) (Tabela 3.). Tijekom osmogodišnjeg razdoblja dokazana su 4353 pozitivna uzorka seruma koza ili 40,62 \% od ukupnog broja serološki pozitivnih uzoraka.

Lančanom reakcijom polimerazom $u$ stvarnom vremenu dokazana je prisutnost genoma lentivirusa malih preživača $u$ 65,5 \% (19/29) pretraženih uzoraka, dok je metodom ugniježđene lančane reakcije polimerazom dokazan odsječak pol gena u 86,2 \% (25/29) uzoraka. Sekvencirano 
je i filogenetski analizirano ukupno devet odabranih uzoraka s umnoženim odsječakom pol gena te je ustvrđeno da osam sojeva podrijetlom od uzoraka iz Međimurske i Varaždinske županije pripada genotipu $B$ (prototip AEK genotipa), a jedan soj podrijetlom od uzorka krvi koze iz Varaždinske županije genotipu A (prototip MVV genotipa).

\section{Rasprava}

Otkako je prvi puta opisana 1974. godine (Cork i sur., 1974.) u Americi bolest je prepoznata i rasprostranjena $\mathrm{u}$ čitavom svijetu prouzročeči znatne gospodarske gubitke (Reina i sur., 2009., Patel i sur., 2012.). Sukladno tome postoji sve veća potreba za stalnom kontrolom uzgoja kao i izrada kvalitetnih programa kontrole i suzbijanja koji bi doprinijeli ograničavanju širenja bolesti. Problem dodatno otežava i činjenica da koze mogu više godina biti inficirane, a da pri tome ne pokazuju znakove bolesti (Peterhans i sur., 2004.). Od presudne važnosti je rano otkrivanje uzročnika kako bi se životinje pozitivne na prisutnost specifičnih protutijela za virus AEK što ranijeizdvojile iz stada. Uz serološke metode napredak molekularne biologije pridonio je izradi osjetljivih testova $\mathrm{u}$ dijagnostici bolesti poput lančane reakcije polimerazom $\mathrm{u}$ stvarnom vremenu (real-time PCR) za dokazivanje prisutnosti provirusne DNK u tkivu i u krvi. Molekularnim metodama moguće je dokazati infekciju prije stvaranja protutijela što omogućuje otkrivanje latentnog provirusa tijekom čitavog životnog vijeka životinje (Brajon i sur., 2012., Ramírez i sur., 2013.).

Posljednja dva desetljeća, u Hrvatskoj je zaraženost koza virusom AEK zabrinjavajuće porasla. Bolest se u nezaražene uzgoje unosi zaraženim životinjama odnosno kupoprodajom što je ujedno i najčešći način širenja bolesti unutar države. Unatoč velikom gospodarskom utjecaju na proizvodnost populacije mliječnih koza educiranost uzgajivača o posljedicama ove bolesti je relativno mala. Izuzetak su uzgajivači sjeverozapadnog dijela Hrvatske u Varaždinskoj i Međimurskoj županiji. Na području tih županija već se godinama provode VIP projekti koji su zasigurno utjecali na osviještenost uzgajivača. Razlozi za neprovođenje programa $u$ Republici Hrvatskoj dijelom su financijske prirode, ali i dijelom u nerazumijevanju krajnjeg cilja provedbe programa od dijela javnosti. Kako bi se razvoj kozarstva u Republici Hrvatskoj poboljšao bilo bi potrebno izraditi odgovarajuću strategiju suzbijanja bolesti, jer bi to imalo pozitivan utjecaj na povećanje proizvodnje uz ista ulaganja.

U Hrvatskoj je prošle godine ukupan broj koza povećan za 3,9 \%, kako pokazuju privremeni podatci Državnog zavoda za statistiku (DZS). Koza je, prema podatcima od listopada 2019. godine, bilo ukupno 85014 (MP, eGlasilo 2019.). Proizvodnja kozjeg mlijeka i mesa je u Hrvatskoj porasla i postaje sve značajniji izvor prihoda i to ne samo na obiteljskim gospodarstvima, već i na područjima na kojima kozarstvo nije tradicijska stočarska grana.

U razdoblju od 2012. do 2019. godine rezultati naših istraživanja pokazali su da je ukupna zabilježena seroprevalencija virusom AEK bila $40,62 \%$, a to možemo objasniti upravo nedostatkom zdravstvene kontrole tijekom godina. Seropozitivne životinje dokazane su u 14 od 16 pretraženih županija. Negativne reakcije utvrđene su u Sisačko-moslavačkoj županiji (3/0) i Dubrovačko-neretvanskoj (9/0) gdje je ujedno pretražen i najmanji broj uzoraka. Najveći broj pretraženih krvi koza dolazio je iz županija sjeverozapadne Hrvatske u kojima je kozarstvo razvijeno, kao što su Međimurska (3 938 krvi) i Varaždinska (3 755 krvi). Ove su županije ujedno i primjer koliko je bitna educiranost i zainteresiranost samih uzgajivača. 
Obzirom na veliki postotak pozitivnih reakcija koji je ustvrđen u Šibenskokninskoj $(67,67 \%)$ i Splitsko-dalmatinskoj $(60,86 \%)$ županiji postavlja se pitanje pravog broja zaraženih životinja $u$ odnosu na sveukupnu populaciju koza. Iz podataka DZS (MP, eGlasilo 2019.) je vidljivo da Splitsko-dalmatinska županija trenutno ima populaciju od 17 034 koza, a u osmogodišnjem razdoblju pretražena su svega 92 uzorka. Slično je i u Zadarskoj županiji s 15600 koza od kojih je tijekom osam godina pretraženo samo 378 uzoraka. Ove dvije županije čine ujedno $38 \%$ ukupne populacije koza u RH pa ne možemo govoriti o realnom stanju proširenosti bolesti, ali zndemo li da jednom zaražena jedinka ostaje doživotni nositelj virusa i može doživotno biti izvor zaraze postavlja se pitanje uspješnosti cijele proizvodnje.

Rezultati višegodišnjeg istraživanja ukazuju na široku rasprostranjenost virusa AEK u uzgojima koza u Republici Hrvatskoj, ali još uvijek ne znamo stvarno stanje o AEK u ukupnoj populaciji koza. U Sloveniji istraživanja provedena 2011. godine na 902 životinje u 22 uzgoja koza (Kuhar i sur., 2011.) pokazuju seroprevalenciju od 29,7 \%, a u jednom uzgoju prevalencija je iznosila $80 \%$. Kasnija istraživanja pokazuju porast seropozitivnih životinja na 32,1 \%, a broj pozitivnih uzgoja $76,2 \%$, a unutar uzgoja seroprevalencija kretala se od 1,5 do 92,2 \% (Kuhar, 2013.). Temeljem seroloških pretraživanja provedenih u Mađarskoj dokazano je da je više od $30 \%$ populacije koza zaraženo virusom AEK (Kusza i sur., 2004.).

Primjena real time PCR tehnologije u rutinskoj mikrobiološkoj dijagnostici značajno raste upravo zbog svoje prednosti brze dijagnostike, osjetljivosti i specifičnosti (Claas i sur., 2007.). Molekularnom metodom lančane reakcije polimerazom $u$ stvarnom vremenu dokazana je prisutnost genoma lentivirusa malih preživača u 65,5 \% pretraženih uzoraka, dok je metodom ugniježđene lančane reakcije polimerazom dokazan odsječak pol gena u 86,2 \% uzoraka. Osim što je u ovom istraživanju primjena ugniježđene lančane reakcije polimerazom (nested PCR) netipično osjetljivija od PCR metode u stvarnom vremenu, važno je istaknuti i činjenicu da $\mathrm{u}$ određenom broju serološki pozitivnih koza (4/29) nije bilo moguće dokazati provirusnu DNK. Niža osjetljivost PCR metode u stvarnom vremenu (79 \%) u odnosu na ELISA test ustvrđena je i u istraživanju slovenskih autora (Kuhar i sur., 2013.b).

Međutim, ne možemo isključiti utjecaj moguće visoke genske heterogenosti sojeva LVMP u Hrvatskoj u okviru saznanja o otežanoj primjeni istih setova početnica u PCR reakcijama za dokazivanje LVMP genoma u različitim geografskim regijama (Barquero i sur., 2013.). Razlozi koji su mogli utjecati na nižu osjetljivost PCR metoda u odnosu na serološke metode je i primjena pune krvi umjesto frakcije leukocita, ali i moguće niska koncentracija provirusne DNA u leukocitima pretraženih koza (Kuhar i sur., 2013.c). Potrebno je svakako istražiti i primjenu dupleks PCR reakcija kojima istovremeno dokazujemo različite regije LVMP genoma što može povećati ukupnu osjetljivost testa (Marinho i sur., 2018.). Smatra se da bi upravo kombinacija ELISA testova i molekularnih metoda bila optimalna za dokazivanje AEK inficiranih koza (Panneum i Rukkwamsuk, 2017.).

Rezultati genotipiziranja odabranih sojeva LVMP ukazuju na cirkulaciju genske skupine A i B u populaciji koza, slično istraživanjima u susjednoj Sloveniji (Kuhar i sur., 2013.a) i to su prva takva istraživanja provedena u Hrvatskoj. Dokaz prisutnosti genotipa A u stadu koza u kojem je istovremeno dokazan i genotip B ukazuje na činjenicu da sojevi LVMP nisu ograničeni na jednu vrstu već da sojevi MVV, koji se uglavnom nalaze u ovaca, cirkuliraju i u koza. Genotipizacija 
sojeva LVMP svakako ima veliku važnost u mogućem otkrivanju izvora infekcije, ali isključivo u kombinaciji s detaljnim podatcima epizootiološkog istraživanja te stoga treba biti uključena u programe iskorjenjivanja lentivirusnih infekcija u malih preživača.

\section{Zaključak}

Zbog nemogućnosti liječenja bolesti i njezinog negativnog utjecaja na gospodarsku proizvodnju mnoge zemlje $\mathrm{u}$ svijetu provode nacionalne programe s ciljem praćenja i suzbijanja bolesti. Iskorjenjivanje bolesti je dugotrajan, zahtjevan i skup proces, ali na kraju s pozitivnim učinkom. Najočitiji primjer je Švicarska koja je primjenom smanjila prevalenciju na manje od $1 \%$, a razina pozitivnih životinja na AEK bila je 0,06 \% čime je ustvrđeno da se bolest više aktivno ne širi i da je uspješno kontrolirana (Thomann i sur., 2017.). U Italiji, u provinciji Bolzano u Južnom Tirolu implementacija programa eradikacije u periodu od 2007. - 2015. godine bila je uspješna pa je prevalencija s 13,9 \% smanjena na $1 \%$ (Tavella i sur., 2018.). Dokazano je da u stada ovaca i koza koja se drže zajedno (miješana stada) može doći do prijenosa virusa s jedne vrste na drugu pa se koze mogu zaraziti virusom MV, a ovce virusom AEK. Važno je znati da jednom inficirana životinja ostaje bolesna do kraja života, s mogućnošću da nikada ne pokaže vidljive simptome. Sve ovo zahtijeva ranu dijagnostiku kao nužnost u spijrečavanju širenja bolesti te ovi rezultati nalažu potrebu nastavka istraživanja kako bi se upotpunile dosadašnje spoznaje $o$ proširenosti bolesti u Republici Hrvatskoj s ciljem njezinog suzbijanja.

\section{Literatura}

1. BARQUERO, N., A. DOMENECH, A. ARJONA, J. F. FERNANDEZ-GARAYZABAL, J. A. RIUZSANTA-QUITERIA and E. GOMEZ-LUCIA (2013):
Comparison of two PCR and one ELISA techniques for the detection of small ruminant lentiviruses (SRLVs) in milk of sheep and goats. Res. Vet. Sci. 94, 817-819.

2. BERTOLOTTI, L., M. MAZZEI, G. PUGGIONI, M. L. CARROZZA, S. DEI GUDICI, D. MUZ, M. JUGANARU, C. PATTA, F. TOLARI and S. ROSATI (2011): Characterization of new small ruminant lentivirussubtype B3 suggests animal trade within the Mediterranean Basin. J. Gen. Virol. 92, 1923-1929.

3. BRAJON, G., D. MANDAS, M. LICIARDI, F. TACCORI, M. MALONI, F. CORRIAS, C MONTALDO, F. COGHE, C. CASCIARI, M. GIAMMARIOLI and G. ORRÙ (2012): Development and field testing of a Real-Time PCR Assay for Caprine Arthritis-Encehalitis-Virus (CAEV). Open Virol. J. 6, 82-90.

4. BRINKHOF, J. M, L. MOLL, C. VAN MAANEN and D. J. HOUWERS (2010): Use of serology and polymerase chain reaction for the rapid eradication of small ruminant lentivirus infections from a sheep flock: a case report. Res. Vet. Sci. 88, 41-43.

5. CLAAS, E. C. J., W. J. G. MELCHERS and A. C. J. VAN DEN BRULE (2007): The role of rel-time PCR in routine microbial diagnostics. In: Real.time PCR microbiology: From diagnosis to characterization. Edited by Mackay I. M. Norfolk: Caister Academic Press, 231-267.

6. CORK, L. C., W. J. HADLOW, J. R. GORHAM, R. C. PIPER and T. B. CRAWFORD (1974): Pathology of viral leukoencehalomyelitis of goats. Acta Neuropathol. 29, 281-292.

7. ČAČ, Ž., M. LOJKIĆ i L. JEMERŠIĆ (1996): Artritis encefalitis koza-Prvi serološki dokaz u Hrvatskoj. Zbornik sažetaka 1.Hrvatskog kongresa mikrobiologa s međunarodnim sudjelovanjem/ Delić Vladimir (ur.). Zagreb: Hrvatsko mikrobiološko društvo, str. 10, Opatija.

8. Č́AČ, Ž., M. LOJKIĆ, B. ROIĆ i L. JEMERŠIĆ (2000): Serološka dijagnostika bolesti artritis-encefalitis koza. Praxis vet. 48, 167-172.

9. DAWSON, M. (1988): Lentivirus diseases of domestical animals. J. Comp. Path 99, 401-419.

10. DRŽAVNI ZAVOD ZA STATISTIKU REPUBLIKE HRVATSKE (2019): Priopćenje : Broj stoke i peradi stanje 1. prosinca 2018. godina. Zagreb 5.travnja 2019., Broj 1.1.21.

11. KOSTELIĆ, A., B. TARIBA, I. LOHMAN JANKOVIĆ, T. KIŠ, Ž. CVETNIĆ, B. ROIĆ, D. MULC, E. BARANAŠIĆ i Ž. LJUBIĆ (2012): Utjecaj iskorjenjivanja artritisa encefalitisa koza na razvoj mliječnog kozarstva u Hrvatskoj. 40. Hrvatski simpozij mljekarskih stručnjaka s međunarodnim sudjelovanjem, Lovran, Zbornik sažetaka, str. 25.

12. KOSTELIĆ, A., B. ROIĆ, Ž. CVETNIĆ, B. TARIBA, T. KIŠ, I. ŠTOKOVIĆ, N. PRVANOVIĆ BABIĆ, D. MULC, P. BAGOVIĆ, D. VINCEK i M. GORUPIĆ (2013): Artritis encefalitis koza u Hrvatskoj. Veterinarski dani, Opatija, Zbornik radova, str. 127-132. 
13. KUHAR, U., D. BARLIČ-MAGANJA, T. ZADNIK and J. GROM (2011): Serološka in molekularnoepidemiološka študija virusa kozjeg artritisa in encefalitisa (CAEV) v slovenskih rejah koza. Slov. Vet. Res. 48, 248.

14. KUHAR, U. (2013): Lentivirusne okužbe v slovenskih rejah kozi n ovac. Ljubljana: Veterinarska fakulteta, 2013., Doktorska disertacija.

15. KUHAR, U., D. BARLIČ-MAGANJA and J. GROM (2013a): Phylogenetical analysis of small ruminant lentiviruses detected in Slovenia. Vet. Microbiol. 162, 201-206.

16. KUHAR, U., D. BARLIČ-MAGANJA and J. GROM (2013b): Development and validation of TaqMan probe based real time PCR assays for the specific detection of genotype $\mathrm{A}$ and $\mathrm{B}$ small ruminant lentivirus strains. BMC Vet. Res. 9, 172.

17. KUHAR, U., D. BARLIČ-MAGANJA, T. ZADNIK and J. GROM (2013c): Molecular and genetic characteritics of small ruminant lentiviruses in Slovenia. Acta Vet. Hung. 61,135-146.

18. KUSZA, S. Z., Z. S. BOSZE, S. KUKOVICS and A. JAVOR (2004): Genetics assay of Caprine arthritis encephalitis int he Hungarian goat herd. South Africa J. Anim. Sci 34, 13-16.

19. KUZMAK, J., A. KEDZIORA, M. ROLA, B. KOZACZYNSKA, Y. CHEBLOUNE and K. GALLAY (2003): Evaluation of PCR/Hybridization method for the detection of caprine arthritisencephalitis virus infection in goats. Bull. Vet. Inst. Pulawy 47, 293-300.

20. LEROUX, C., J. CHASTANG, T. GREENLAND and J. F. MORNEX (1997): Genomic heterogeneity of small ruminant lentiviruses: existence of heterogeneous populations in sheep and of the same lentiviral genotypes in sheep and goats. Arch. Virol. 142, 1125-37.

21. MARINHO, R. C., G. R. MARTINS, K. C. SOUZA, A. SOUZA, S. SILVA, J. A. NOMBRE and M. TEIXERIA (2018): Duplex nested-PCR for detection of small ruminant lentiviruses. 49 Suppl 1, 83-92.

22. MINISTARSTVO POLJOPRIVREDE (2019): Izvješće o stočarskoj proizvodnji. eGlasilo 10/ 2019., str 3.

23. NARAYAN, O. and L. C. CORK (1985): Lentiviral diseases of sheep and goats: chronic pneumonia, leukoencephalitis and arthritis. Rev. Inf. Dis. 7, 89-98.

24. OIE (2008): Manual of diagnostic tests and vaccines for terrestial animals. 6. ed. Paris:OIE.

25. OLECH, M., N. RACHID, B. CROISE, J. KUZMAK and S. VALAS (2012): Genetic and antigenetic chsracterization of small ruminant lentiviruses circulating in Poland. Virus. Res. 163, 528-536.

26. OLECH,M., S. VALAS and J. KUZMAK (2018): Epidemiological survey in single-species flocks from Poland reveals expanded genetic and antigenic diversity of small ruminant lentiviruses. PLOS ONE 13 (3): e0193892.https://doi.org./10.1371/ journal.pone.0193892.

27. PANNEUM, S. and T. RUKKWAMSUK (2017): Diagnosis of Caprine Arthritis Encephalitis Virus infection in dairy goats by ELISA, PCR and Viral culture. Pol. J. Vet. Sci. 20, 247-353.

28. PATEL, J. R., J. G. M. HELDENS, T. BAKONYI and M. RUSVAI (2012): Impotrant mammalian veterinary viral immunodiseases and their control. Vaccine 30, 1767-1781.

29. PETERHANS, E., T. GREENLAND, J. BADIOLA, et al. (2004): Routes of transmission and consequences of small ruminant lentiviruses (SRLv) infection and eradication schemes. Vet. Rec. 35, 257-274.

30. RAMÍREZ, H., R. REINA, B. AMORENA, D. D. ANDRÉS, and H. A. MARTÍNEZ (2013): Small Ruminant Lentiviruses: Genetic Variability, Tropism and Diagnosis. Viruses 5, 1175-1207.

31. REINA, R., E. BERRIATUA, L. LUJAN, R. JUSTE, A. SANCHEZ, D. DE ANDRES and B. AMORENA (2009): Prevention strategies against small ruminant lentiviruses: an update. Vet. J. 182, 31-37.

32. REINA, R., L. BERLLOTI, S. DEI GUDICI, G. PUGGIONI, N. PONTI, M. PROFITI, C. PATTA and S. ROSATI (2010): Small ruminant lentivirus genotype $\mathrm{E}$ is widespread in Sarda goat. Vet. Microbiol. 144, 24-31.

33. SHAH, C., J. BÖNI, J. B. HUDER, H. R. VOGT, J. MÜHLHERR, R. ZANONI, R. MISEREZ, H. LUTZ and J. SCHÜPBACH (2004): Phylogenetic analysis and reclassification of caprine and ovine lentiviruses based on 104 new isolates: evidence for regular sheep-to-goat transmission and worldwide propagation through livestock trade. Virology 319, $12-26$.

34. TAVELlA, A., A. BETTINI, M. CEOL, P. ZAMBOTTO, E. STIFTER, N. KUSSTATSCHER, R. LOMBARDI, S. NARDELI, M. S. BEATO, K. CAPELLO and G. BERTONI (2018): Achievements of an eradication program against caprine arthritis encephalitis virus in South Tyrol, Italy. Vet. Rec. $182,51$.

35. THOMANN, B., L. C. FALZON, G. BERTONI, H. R. VOGT, G. SCHÜPBACH-REGULA and I. MAGOURAS (2017): A census to determine the prevalence and risk factors for caprine arthritis- encephalitis virus and visna/maedi virus in the Swiss goat population. Prev. Vet. Med. 137, 52-58.

36. TORSTEINSDOTTIR, S., H. M. CARLSDOTTIR, V. SVANSSON, S. MATTHIASDOTTIR, A. H. MARTIN and G. PETURSSON (2007): Vaccination of sheep with Maedi-Visna virus gag gene and protein, beneficial or harmful? Vaccine 25, 67136720. 


\section{Arthritis Encephalitis Virus in goats in the Republic of Croatia in the period from 2012 to 2019: serological and molecular research}

Besi ROIĆ, DVM, PhD, Scientific Advisor, Dragan BRNIĆ, DVM, PhD, Scientific Associate, Andreja JUNGIĆ, DVM, PhD, Expert Advisor, Croatian Veterinary Institute, Zagreb, Croatia; Zdravka ROMAC, DVM, PhD, Postdoctoral Student, Croatian Veterinary Institute, Veterinary Department Split, Croatia; Lorena JEMERŠIĆ, DVM, PhD, Associate Professor, Tomislav KEROS, DVM, PhD, Scientific Advisor, Jelena PRPIĆ, Molecul. Biol., PhD, Scientific Associate, Croatian Veterinary Institute, Zagreb, Croatia; Antun KOSTELIĆ, DVM, PhD, Associate Professor, Faculty of Agriculture, Zagreb, Croatia; Dragutin VINCEK, PhD, Administrative Department of Agriculture, Varaždin County, Croatia

Caprine arthritis and encephalitis (CAE) is a contagious and an economically important viral disease of goats. Caprine arthritis encephalitis virus (CAEV) is a member of the small ruminant lentiviruses (SRLV) that is distributed worldwide, including Croatia. Common symptoms resulting from CAEV infection include arthritis, pneumonia, indurative mastitis and encephalitis. One of the first and most common signs of CAEV infection is weight loss. However, many goats will not show any symptoms. Goats that do show symptoms may display swollen knees or carpal joints, exhibit reduced body condition, and develop a rough hair coat. Pregnant and nursing does display a hard udder that is firm and swollen, and produce very little milk. During 2012 to 2019, a total of 10,715 blood serum samples were collected in 16 counties in Croatia and examined for the presence of CAEV specific antibodies using ELISA. Antibodies against CAEV were confirmed in $4353(40.62 \%)$ of samples. As this is the first such study to be carried out in Croatia, the results of molecular testing of selected SRLV strains indicate the circulation of the $A$ and $B$ genotypes in the Croatian goat population. The simultaneous presence of both genotypes A and B in a goat herd suggests that SRLV strains are not limited to one species, and that Maedi visna virus (MVV) strains, which are mainly detected in sheep, also circulate in goats. The results of this eight-year study conducted by the Croatian Veterinary Institute (CVI) indicate the widespread prevalence of SRLVs in goat breeding in Croatia. It is known that once an infected, the individual remains a lifelong carrier and can spread the virus. This raises the issue of the success of entire production. In conclusion, the only long-term sustainable goat breeding is on CAEV-free goat farms.

Key words: arthritis-encephalitis virus; goats, seroprevalence; polymerase chain reaction; phylogenetic analysis 